\title{
Female Muslim Factor in Preservation of Ethnocultural Traditions of the Tatar Society (XIX - XX Centuries)
}

Adelya Ilhamovna Sattarova

Kazan Federal University

Anvar Ajratovich Gafarov

Kazan Federal University

Rinat Ahmatgalievich Nabiyev

Kazan Federal University

Doi: 10.36941/jesr-2019-0020

\section{Abstract}

The article discusses a range of issues related to the role of the female Muslim factor in the preservation and development of the ethnocultural traditions of Tatar society in the late XIX - XX centuries. The article discusses a range of issues related to the role of the female Muslim factor in the preservation and development of the ethnocultural traditions of Tatar society in the late XIX - XX centuries. The evolution of the ideas of Tatar Muslim theologians about the role of women in the family and society is noted. In the context of the specific changes in the life principles of Russian Muslim women, the content of the dichotomy of cadimism and jadidism is revealed: in the form of rivalry between the obsolete form of religious and cultural life (cadimism), on the one hand, and the renewed system of spiritual values (Jadidism), on the other. The importance of new educational practices in the emancipation of Muslim women is shown. Shows the origins of the formation of social institutions and organizations of Muslim women, the process of changing their traditional way of life and forms of self-identification within the framework of the ethnic and religious tradition. The features of the ethnocultural life of Tatar women under the dictates of the political and ideological system of the Soviet period and the main trends in the manifestation of the female factor in the processes of ethnic and religious revival of the peoples of Russia in the post-Soviet period are highlighted.

Keywords: Muslim women, gender, cadimism, Jadidism, Tatar-Muslim women's organizations, Islamic culture, ethnocultural traditions

\section{Introduction}

Spiritual and cultural traditions are an important element of ethnic culture, which serves as the basis for the interaction of the material, spiritual, and social life of an ethnos. Despite the cultural unification, the Tatar national identity, which was formed at the end of the XIX century, still plays a significant role in the socio-cultural life of modern Tatarstan. Russian society, freeing itself from ideological accretions, is gradually returning to history the ancestral traditions and values verified by history. This process, in which the female plays the dominant role, seems to be a topical issue. It is considered in line with the revival and development of the ethnocultural traditions of the Tatar society.

Turning to the origins of this problem, it should be noted that a woman in Volga Bulgaria 
initially had a fairly high social position. She had the opportunity to participate in the discussion of key issues on an equal basis with men. Ibn Fadlan wrote that at the ceremonial reception of the Great Arabian Embassy (922) the Bulgarian Tsarina sat next to the king, "such is their law and custom" [Travel Ibn-Fadlan on the Volga ,1939, p. 67-68]. Many legends have preserved the historical memory of the girls of the "country of cities", Al-tynchech, Karakuz, Gaishabike, who stood next to men to defend their homeland [Biktimerova T.A. 2019; Ahmadi, et al 2014; Radhy, 2019; Issaliyeva, et al 2018]. The enlightenment of Bulgarian women was noted by the Arab geographer Ibn-Ruste [News about the Khazars, Burtases, Bulgarians, Magyars, Slavs and Russias Abu-ali Ahmed bin Omar Ibn / 1869]. This is largely due to the fact that in the XII - XIV centuries. a significant network of educational institutions was formed here. Since the end of the XIV century. The Kazan Khanate, which became a prominent economic, political and cultural center, took over the baton of the region's spiritual and cultural heritage. Despite the subsequent cataclysms, the ethnocultural educational traditions of the Tatars continued to develop in the future. The high literacy of Tatar women was noted by P.I. Rychkov [1769 and 1770, p. 6], K.F. Fuchs [1991, p. 3637] and many other researchers.

It is obvious that the initial sociocultural gender traditions of the Tatar people were an important factor in the preservation and development of their ethnocultural identity.

\section{Methods}

The issue of cultural identification of Muslim women, their position in the family, sociocultural and sociopolitical sphere becomes more urgent with the advent of the New Age - as the processes of modernization of the Muslim community develop [Gafarov A.A. 2014]. Starting from this period, there are active searches of theoretical and methodological approaches to an adequate understanding of the gathering processes [Gafarov A.A., Nabiyev R.A., Fazliev A.M., Nafikov I.Z;2017]. Many prominent thinkers and public figures of the Muslim East have been studying this topic in the past: M.F. Akhundov, A. Bayazitov, S.G. Sultanov, A. Agaev, Z. Kamali et al. [2015]. At the end of the XIX century. M. Bigiyev, an eminent Tatar philosopher and theologian, published a series of articles directly affecting the women's issue in Muslim society [M. Bigiyev. 2006.].

People's Enlightener Mukhlisa Bubi, who had been in charge of the family department at the Muslim Board for 20 years, also devoted a number of works to this topic. Among the actual issues raised by it - the problem of polygamy. In the journal "Syuyumbike" (1917) appeared the material "Marriage with more than one woman" by Mufti G. Barudi [2003] and Muslim judges (Kadiyev), among whom was M. Bubi. Soon "Muslim magazine" published its article "Women." In it M. Bubi pays attention to parental responsibilities. Subdividing the period of growing up into three stages (childhood, adolescence, adolescence), it gives each period a characteristic and explains in detail from the standpoint of Islam the duties of parents towards children [Gimazov R. Muhlisa Bubi and the enlightenment of Muslim women. - 2019].

A public figure, educator, Kadi and future mufti R. Fakhretdin also devoted a number of works to the development of Muslim culture. They reflected his attitude towards European science, education and the emancipation of women. They published textbooks, manuals, popular brochures (more than 60 works) on the problems of ethics, pedagogy, education of the younger generation [Muhamadiev B.M. 2011, p. 92]. Fahretdin's research in this area remains relevant to this day. His educational and pedagogical heritage was reflected in the works of A.Kh. Makhmutova, R.N. Musina, L.I. Almazovoy, A.B. Yunusova, L.F. Baybulatova and others.

\section{Results and Discussion}

In the late nineteenth - early twentieth centuries. the Muslim world of Russia embraced the modernist movement, the most important element of which was school reform (Usul-i-Jadid - a new method); she contributed to the renewal of the whole way of life of Russian Muslims [6, p. 243-288]. The training courses of Muslim educational institutions introduced the teaching of general educational disciplines, progressive elements of European didactics. By the beginning of the twentieth century. $90 \%$ of all mektebov and madrasas joined the new methodical direction [Nafigov 
R.I. 1964, p. 3, 269]. The development of secular education has become a powerful catalyst of the Muslim women's movement.

For the Jadidis, the issue of the education and enlightenment of women was one of the key questions. They clearly outlined the position stating the need to improve the social status of women. Training women is a guarantee not only of their sociocultural adaptation, but also of the advancement of the whole nation. As an integral participant in social construction, she bears a gigantic responsibility for the cultural reproduction of the nation, and accordingly should receive the best education.

Thanks to the asceticism of G. Barudi and his wife Magruy in 1890 in Kazan, the first women's new method school appeared. Following her, such educational institutions appeared throughout Russia. The schools of R.S. Amirkhania, L. Khusainova, M. Muzaffaria in Kazan, F. Gainutdinova, F. Agdamova, M. Rameeva in Chistopol, B. Mukminova in Orenburg, G. Biktimerova in Kasimov, $\mathrm{H}$. Urmanova in Blagoveshchensk. Women's schools appeared in Ryazan, Astrakhan, Simbirsk, Tomsk and other cities. The Bubi madrasah became a major educational center for women's education (Izh-Bobya village, Sarapulsky district, Vyatskaya province). Here "religious sciences occupied only $16 \%$ of the total subjects taught" [Vakyt. - 1908.]. Bubi contemporaries considered as a higher Tatar school. By 1905, only in Kazan Province. there were 845 Tatar mektebov and madrasahs, where 34860 boys and 19599 girls studied. A generation of active and educated, liberated Muslim women has been formed in numerous new-method schools.

At the same time, the government actively implanted state Russian-Tatar schools. The key subjects there were Russian and arithmetic; The basics of history, geography, and natural history were also taught. The basic language of teaching was Russian, in Tatar only religious discipline was taught. The administration attached particular importance to the creation of female RussianTatar schools. Back in 1861, the Orenburg Provincial Gazette wrote: "It's time to be convinced of this immutable truth that the education of every nation should start with a woman ... A woman is set by nature by the teacher of her children." In this regard, it is important to involve in the RussianTatar schools "as many as possible daughters of foreigners" [Biktimirova T., Hamitbaeva N. TatarkiEnlightenment // 2019]. At the beginning of the XX century. The number of such schools has increased significantly thanks to official and private support.

The emergence of new schools has led to an acute shortage of teachers. In the XIX - early XX centuries. teacher training has expanded substantially. A scientific and pedagogical center for the training of teachers of Tatar schools appeared at the "Bubi" madrasa. Over the three years of his work (1908-1911), 274 teachers have received vocational education here, 106 of whom are women [15]. Objective needs prompted Orientalist Lebedev, OS take the initiative about the possibility of Muslim Tatars to establish their own university [Lebedeff O. 1899, p. 90-91].

The expansion of gymnasium education among Muslims, including external studies, as well as the emerging private gymnasiums (in Orenburg, Ufa, Troitsk Kazan) opened the way for them to receive higher public education. A large role in this direction was played by the Kazan Higher Women's Courses. Until 1917, they graduated from Z. Akhmerov, K. Maksudov, R. Gabitov, M. Mukhutdinov, Z. Rakhmankulov, M. Yunusov, F. Devletkildeeva, M. Gubaidullin, S. Gafarov, Z. Gafurov. The daughters of the court counselor I.A. Vagapova - Zuleikha and Madina. At the medical faculty of the Kazan University, R. Gubaev (Kutlubaeva), A. Teregulova, A.-B. Gubeeva, U.-G. Gubeeva et al. [2003].

The trends of renewal could not touch the clothes of Muslim women, their living conditions. In the XIX century. the national costume of tatars (not without the influence of Russian fashion) has changed significantly [5, p. 70]. Shops offering fashionable clothes brought from Europe gained wide popularity among Tatar people. A rather unusual hobby of Muslim women was the theater, which contributed to the greater publicity of their private life [Schiele. 1979, p. 26]. However, more significant changes in the field of the spiritual life of Tatar women, their way of life and status manifested themselves only by the end of the XIX - beginning of the XX centuries.

The socio-economic, domestic, cultural space of Muslim women rather slowly entered the process of modernization. At the same time, permanent sociocultural, economic contacts with the Russian population, travel could not but have an impact on the public consciousness of the Tatars. At first, manifestations of emancipation were sporadic, as evidenced not only by researchers, but 
also by heated debates on the women's issue in the Islamic press, as well as at the First AllRussian Muslim Congress (Moscow, 1917).

The boom of the literary activity of Muslim women is noteworthy. In their works, they tried to attract the reading public to the topical issues of our time (M. Akchurin, Mag. And Mach. Muzaffariya, H. Nasyriyya, F. Suleymaniyah, etc.). The literary works of G. Biktimirov from the village of Yaubash, Ryazan Province, which organized a school for girls in her village, at the end of the 19th century. prompted to understand the role of women in the family and methods of raising children: "Encouraging girls", (1892, 1897), "Beautiful guardian" (1895, 1899), "Ethics of communication" $(1895,1899)$. In the subsequent period, the volume of publications of Muslim women has steadily increased. It is noteworthy that R. Fahretdin was the publisher of the Ethics of Communication (1899). As a result, his advice and instructions were included in Biktimirova's book [1899, p. 21-23].

Using an analysis of the scriptures, R. Fakhretdin attempted to update the ideal of a woman, emphasizing her education as a pledge of the progressive development of society. As examples for imitation, he proposed vivid images presented in the series Famous Women, where he published the texts of the books Educated Mother (1898), Educated Wife (1899). Following him, Mukhlis Bubi, in a number of articles published in Tatar newspapers and magazines Ulfat, Akhbar, Vakyt, Syuyumbike, Islam Majallas, sought to draw attention to the role of women in the preservation and development of religious-national traditions.

In some Tatar editions there appeared rubrics devoted to the "women's issue". A remarkable fact was the appearance in 1913 in Kazan of the women's magazine "Syuyumbike". The famous theologian, public and political figure, journalist Z. Kadiri in many of his articles examines issues related to the infringement of the rights of women. National playwrights and novelists (Z. Bigiyev, G. Ilyasi, F. Khalidi, G. Iskhaki, and others) did not avoid the issue of women. In their works, they made calls for the moral and moral emancipation of women.

A special influence on the movement of Muslim women had Russian feminists. Their organizations that emerged during the years I of the Russian revolution ("Women's Progressive Party", "Russian Women's Mutual Charitable Society", "Russian League for Women's Equality") set an example. Having originated in the field of charitable associations, women's organizations powerfully declared themselves in the social life of Russia in the turning point of 1917.

The Soviet period was a time of increasing the socio-cultural role of women. One of the key tasks of the new, Soviet school was the fight against illiteracy. Despite the high level of confessional education among Tatar, it did not correspond to the tasks and needs of the time. There were special commissions; in the short courses there was a training of teachers. New pedagogical educational institutions for women of local nationalities have appeared. The organizers of this work were Tatar activists, such as S. Akhtyamova, M. Bakhtiyarova, M. Ismagilova, Z. Burnasheva, G. Nurmukhametova, Sh. Khaliullina, sisters Yaushevy and others. The efforts of these ascetics led the work to educate the new generation of Tatar teachers. One-year and short-term summer courses were created for the women's departments. Tartar women's meetings and conferences were held, the activities of women's clubs were developed, where propaganda and clarification of laws extending the rights of women was carried out .

An important step was the involvement of tatarok in scientific activities, which was the result of significant cultural and educational developments. As a result of the feminization of domestic science in the humanitarian departments of universities, the proportion of men was in the mid1990s. about $40 \%$. In pedagogical universities, this figure was $30 \%$, in technical - about $57 \%$ [Alimova E.F. 2002]. These figures certainly indicate an increased intellectual potential of women.

However, female Muslim activism, which gained momentum during the revolution, was broken during the Soviet period. The official Bolshevik policy of unifying the socio-political and spiritual life rejected the religious mentality as hostile and reactionary. The destruction of the Soviet model of social order created at the end of the 20th century. conditions for public initiatives aimed at the full development of the movement of Muslim women.

This period, both in Russia and around the world, was marked by processes of ethnic and religious revival. Along with the growing interest in Islam by young people and the media, this is evidenced by the activation of Muslim women in many spheres of public life. The atheistic legacy of 
the Soviet era and the prevailing stereotypes on the one hand, the enthusiasm of the religious and revivalist atmosphere on the other, are pushing the modern Muslim women to participate in educational work, raising a new generation.

At the same time, the religious "explosion" that took place brought the Russian society out of a state of relative equilibrium: it gave rise to a complex of new political and socio-cultural problems. The violation of religious and cultural traditions contributed to the spread of marginal ideas in this field. In connection with this problem, the leadership of the Republic of Tajikistan and the DUM of the Republic of Tajikistan have repeatedly pointed out the need to restore the traditions of the muftiates of the OMDS-TsDUM. In the greeting of M. Shaimiev to the II All-Russian Congress of Orientalists in 1999, a call was voiced to revive the ideological potential of Jadidism. In 2012, a round table "Woman in the Light of the Holy Quran" was organized. In 2010, with the participation of the Executive Committee of the World Congress of Tatars and DUM RT, a conference was held on the "Revival of the spiritual and moral traditions of the family and the institution of matchmaking in modern conditions". The conference was organized by the Union of Muslim Women of Tatarstan. The fact that the event was attended by representatives of the state power of the Russian Federation testified to the attentive attitude of the state to the revival of cultural Muslim traditions in modern conditions.

Russian orientalists N.F. Katanov, N.I. Ashmarin, V.V. Barthold and others. Even the XIX century. drew attention to the unconditional connection between religious reform and the expansion of secular elements of culture among the Tatars. It is obvious that the emancipation of Muslim women developed in line with the transformation of the entire complex of the socio-cultural tradition of an Islamic society. Although N.F. Katanov in the series of articles "The Muslim peoples' view of a woman" (1900) and considered this question in a strictly traditional framework [Katanov N. 1900, p. 426], it is obvious that as the Europeanization of living conditions and the emergence of secular education, innovations penetrated into the female environment.

In the Volga region, the influence of traditional Muslim institutions was initially manifested with less intensity: local customs played a significant role. For example, Tatar women did not wear the veil; Fees and polygamy were not widely spread. Although, of course, the size and shape of Tatar social activities varied from place of residence, social, material rank and other conditions. Some Muslim women who owned large assets participated in financial and commercial operations, founded charitable foundations to support cultural, educational and religious organizations.

At the beginning of the XX century. the women's Muslim movement has gained a nationwide scale, it manifested both conventional and institutional maturity. This was due, on the one hand, to the evolution of traditionalist Islamic claims, and on the other, to the actualization of women's problems in an era of revolutionary change. The Muslim modernist project in Russia attempted to adapt the ideas of democracy and civil society on the basis of traditional identity.

Despite the deformation in the Soviet period, the confessional component of the worldview did not completely disappear. Against the background of apparent secularization since the late 70s. In the twentieth century, a stormy process of religious revival unfolded, activating the reception of historical experience [Nabiyev R.A., Gafarov A.A. 2015]. This phenomenon, in our opinion, is related to the fact that Muslim women, thanks to gender specificity, managed not only to preserve traditional spiritual and cultural values, but to adapt them to the conditions of modernization and the needs of the newest time. These processes again raised the issue of Islamic feminism and turned their research gaze to its historical experience.

\section{Conclusions}

In the search for ways of sustainable development of Russian society, ethno-confessional traditions appear to be a significant factor in its spiritual and moral recovery. An important role in this process is called upon to play the female Muslim factor. The Jadids of the pre-revolutionary period paid close attention to this issue. The principles and approaches to the revival of spiritual and cultural traditions that emerged in the framework of the Jadid wave of modernization of the Tatar-Muslim community are relevant and demanded in modern conditions. Revived religious institutions in the field of education, halal industry, the system of hajj, matchmaking, nikah, etc., have become a 
factor in the structuring of the modern ummah. The main directions of spiritual revival are reflected in the modern procedures of preparing Muslim women for family life, the return of external ethnocultural and religious paraphernalia, in the conduct of socially significant events promoting ethno-confessional traditions of family culture.

The theme of the historical background of the growing role of the female Muslim factor in Tatarstan society draws attention to the initially high social status of the Tatar, which has developed historically. Beginning with the Volga Bulgaria, as well as at subsequent stages of history, this promise did not disappear, receiving an additional impetus to development during the period of modernization of the Muslim community in the 19th - early 20th centuries. Due to this circumstance, as well as an objective gender specificity of social status, Muslim women of Tatarstan largely managed to preserve the cultural traditions of their ancestors, to carry them through periods of religious persecution and spiritual unbelief to real generations.

\section{Acknowledgements}

The work is performed according to the Russian Government Program of Competitive Growth of Kazan Federal University.

\section{References}

Alimova E.F. Woman in science and education: historical and sociological analysis. Education, employment, career: strategy and tactics of E.F. Alimova // Mater. int. scientific and practical conf. - Kazan, 2002. - p. 36-37.

Ahmadi, A. K., Zamani, M., \& Sarzaym, M. (2014). A survey of the spiritual intelligence in organizations with an emphasis on Islamic texts. UCT Journal of Social Sciences and Humanities Research, 2(2), 29-36.

Biktimirova T., Hamitbaeva N. Tatarki-Enlightenment // Actual National Cultural Review "ANKO" / Tamina Biktimirov, Nail Khamitbaeva. - 2001. No. 3. - URL: https://www.tataroved.ru/institut/center/publ/2 (appeal date: 12.02.2019).

Biktimirova T.A. Education steps to the Sorbonne / T.A. Biktimirov. -Kazan: Alma-Lit, 2003. - 184 p.

Biktimirov G. Megashərət ədəbe / G. Biktimirov. - SPb., 1899. - 23 b.

Biktimerova T.A. Tatar woman in the mirror of history. - URL http://www.tataroved.ru/institut/center/publ/1/ (appeal date: 12.02.2019).

Fuchs K. Kazan Tatars in statistical and ethnographic relations. Kazan, 1844 / Reprint reproduction with the application of the Preface N.F. Katanova for publication in 1914 - Kazan: Tyak Foundation, 1991. - 210 p.

Gafarov A.A. Russian Muslims in the context of general Islamic modernization (XIX - early XX centuries) / A.A. Gafarov. - Kazan: Kazan publishing house. University, 2014. - 564 p.

Gafarov A.A., Nabiyev R.A., Fazliev A.M., Nafikov I.Z. "Muslim matter" in the mirror of public discussion (XIX beginning of the 20th century) / A.A. Gafarov, R.A. Nabiyev, A.M. Fazliev, I.Z. Nafikov // Journal of Fundamental and Applied Sciences. - 2017. - No. 9 (7S). - pp. 1257-1265.

Gafarov A.A. Russian Muslims Lifestyle Renovation Problems in the 19th and Early 20th Century // Journal of Sustainable Development. - 2015. - Vol. 8, No. 7. - pp. 178-184.

Gimazov R. Muhlisa Bubi and the enlightenment of Muslim women. - URL: http://www.islamisemya.com/ (access date: 13.01.2019).

Issaliyeva, A., Ospanova, A. N., \& Alibekul, A. (2018). Kazakhstan and GCC: Islamic component in joint collaboration. Opción, 34(85-2), 205-220.

Katanov N. The view of Muslim peoples on a woman / N.F. Katanov // Activity. - 1900. - № 10. S. 425-426.

Muhamadiev B.M. The main milestones in the life of Rizaetdin Fakhretdinov - a scientist, educator and public figure / B.M. Mukhamadiev // Scientific Tatarstan - 2011. - № 2. - P. 90-94.

Lebedeff O. Abrege de l'histoire de Kazan, offert aux membres du XII Congres des orientalistes / Olga Lebedeff. - Roma: Societa Editrice Dante Alighieri, 1899. - 97 pp.

M. Bigiyev. Selected Works: In 2 t. / Mussa Bigiyev; per. with the Ottoman. A. Khairutdinova. T. II. - Kazan: Tatar. Prince publishing house, 2006. - 336 p.

Nafigov R.I. Formation and development of advanced Tatar socio-political thought. (Essay on the history of 1895-1917) / R.I. What for - Kazan: KSU, 1964. - 444 p.

Nabiyev R.A., Gafarov A.A. XX Centuries: Phenomenon of Religious Revival in the Muslim Community of the Muslim Community in the Late XIX - Early XX Centuries // Journal of Sustainable Development. - 2015. Vol. 8, No. 4. - pp. 253-259. 
News about the Khazars, Burtases, Bulgarians, Magyars, Slavs and Russias Abu-ali Ahmed bin Omar Ibn / per. and comments. YES. Chvolsona. - SPb, 1869. - $199 \mathrm{p}$.

Radhy, Z. H. (2019). Application of Multiply Regression Linear Model and New Technology Method in Estimating Learning and Education of Students. International Electronic Journal of Mathematics Education, 14(1), 87-90. https://doi.org/10.12973/iejme/3978

Schiele. Kazan Tatars. Ethnographic essay // Nature and people. - SPb., 1979. - № 1 (January). - pp. 1-26.

Travel Ibn-Fadlan on the Volga / Per. and ed. I. Krachkovsky. - M.-L .: AN SSR, 1939. - 228 p.

The journal or the travel notes of captain Rychkov in various provinces of the Russian state, 1769 and 1770. $\mathrm{SPb}, 1770 .-189 \mathrm{p}$.

Vakyt. - 1908. - September 27th.

Yusupov M.Kh. Galimdzhan Barudi. - Kazan: Tat. Prince Publishing house, 2003. - 208 p. 